\title{
Avaliadores Ad Hoc
}

Agradecemos aos avaliadores e avaliadoras ad hoc desta edição:

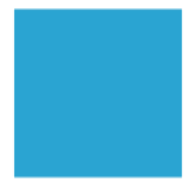

Revista

Extensão

em Foco
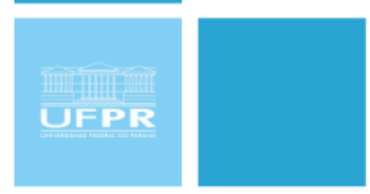

ISSN $\quad 2358-7180$ 